\title{
Supply chain management to boost the processes efficiency of the Algerian small and Mid-sized companies
}

\author{
Amine Ghoumrassi ${ }^{1}$, Habib Kabalan ${ }^{1}$ and GabrielaTigu ${ }^{1}$ \\ ${ }^{1}$ Bucharest Academy of Economic Studies, Bucharest, Romania \\ E-mail: ghoumrassi.amine@ @otmail.fr
}

\begin{abstract}
With the continuous development of the international market, third world countries find themselves having to face the effects of globalization and fight against international companies. Third world countries' local industries and companies must catch up with the current technologies and strategies to be able to stand a chance in the current world set up and ensure their financial security and maintain their share of the local market. North African companies and in particular Algerian companies started to organize regular meetings and workshops to stay up to date with the modern ways of management, reducing costs and having an efficient process. This became an essential point for the Algerian companies to survive globalization and the presence of international companies in the local market. Supply chain management, according to the literature reviews, proved to be a great success influencer in this matter. Algerians small and mid-sized companies are now moving toward the usage of supply chain management to decrease their operational costs as well as their overall costs, increase their market share, improve their financial turnaround, and ensure their safety in the tight competition from the big conglomerates of multinational companies. The aim of this paper is to study and highlight the impact of supply chain management on the processes of the Algerian small and mid-sized companies. The impact will be measured by financial data provided by the company "El Auras" in a comparative table showcasing the difference between the financial data before and after the implementation of supply chain management. To backup the numbers, a non-instructed interview has been carried at the company, a total of 22 managers from different departments participated in the interview process; the results were coded and labelled using Nvivo software to easily analyze them.
\end{abstract}

Keywords: Supply chain management (SCM), Small to Medium Size Enterprises (SMEs), Algerians enterprises, boost efficiency, competitive management, strategic management

\section{Introduction}

Back in the days of the origins of trading practices, traders were focused solely on the financial aspects of the activity, which means the financial outcome of the trading operations. With the continuous development of the trading concept and the technological progress, trade or what came to be known as businesses took another form, a more advanced form. The swift emergence of the international market and the quick growth of international companies, that replaced the traditional aspect of local or regional limitations, have pushed small and mid-sized companies to either adapt to the new practices or risk going under and eventually disappearing altogether. 
Businesses have been forced to maximum their efforts and to work hard to survive the competition at both local and international market levels. This is the case of many Algerian businesses. Algerian businesses have been the same since they were first formed and established in the market. Historically speaking, changes in management approaches were either minimal or non-existent at all since the start of their operations. With the adhesion of Algeria to the World Trade Organization, the Algerian government found itself obliged to waive some customs policies to be compliant with the international regulations and practices. Businesses that were sheltered by customs and protectionist government policies found themselves bare and forced to adapt to new practices to ensure their survival in the local market. Algerian businesses, operating in what is classified as a third world country, have limited knowledge and experience in modern trading practices and technology. This limitation is mainly due to several political and cultural barriers.

The aim of this paper is to assess the impact of supply chain management on process performance and the overall results of small and mid-sized Algerian businesses. This paper will use the balanced scorecard as a way of measuring the process performance using financial data provided by "El Auras" Company. This research will be subjected to a quantitative study, comparing the company results before and after adapting the supply chain management practice to obtain a clear vision of the impact of the supply chain management over a few selected processes and the overall results of the company.

\section{Literature review}

Many researchers confirm the hypotheses of the positive impact of supply chain management on the overall results of the company, many articles and conferences demonstrated that supply chain management can be used as a tool to increase and maintain competitive advantages if well managed and adapted to the company's objectives. For instance, many researchers converged on the concept that the business must perform not only up to the customer's expectation levels but also better than competitors.

The supply chain management ensures the movement and the storage of all the necessary objects from the point of origin to the point of the consumption, using the best moving ways and methods to achieve the customer satisfaction at lowest costs, Thatee, (2007) stated that supply chain responsiveness shall reduce the costs, while leading to competitive advantage for firms on other dimensions as well. Felea și Albăstroiu (2013) affirm that a typical supply chain management is a network of material, information, and services linked with the scope of processing under the supply chain characteristics, transformation and demand. According to Wong and Wong (2007), the efficient management of an organization's supply chains is an essential cornerstone for the organization to develop a sustainable competitive advantage and remain at the forefront of excellence in a competitive market. In order to achieve an efficient supply chain, evaluating the performance of the entire supply chain is extremely important (Najmi et al., 2013).

Aside from the customer focus, supply chain management has several impacts on the internal processes of the businesses. For instance the supply chain management uses the best storage practices to ensure the safety of the products which results into a positive performance of the inventory indicators, this is not the only indicator affected by the supply chain management, many other indicators such as:

- Production: An efficient supply chain can ensure the right raw material is continuously arriving to the production area at the correct time, if the supply chain breaks down prior to the raw material arriving, the manufacturer would be obliged to seek alternatives which results into a delay in the delivery time and perhaps cause schedule changes for workers which will impact the workers satisfaction.

- Full control of costs: The main objective of the supply chain management is the full usage of the assets and ensuring the best financial and assets turnaround.

- Social impact: Supply chain management has a big impact on the social side of the workers, supply chain management encourage the usage of automatic processes and systems, especially in the Algerian market were most businesses still use the manual workforce, counting on the 
Thoth Publishing House

physical effort of the workers, at the end of the day, the workers are exhausted and leaving to their houses exhausted which lead into a bad social life. The supply chain management instead propose the usage of robots that aren't affected by human impacts such as humans fatigue, feelings,...etc.

Other researchers described several other benefits associated to supply chain management integration and its impact on business processes, Trkman and Groznik (2006) says that the supply chain management integration enforce the process of information sharing within the business and outside the business. They also argued on the fact of the supply chain management allow businesses to do a renovation of the business process modelling that increases the profitability. Several other supply chain management benefits were discussed by several other researchers, eg: Li, Ragu-Nathan, RaguNathan, \& Rao (2006), said that the supply chain management allow the business to gain a competitive advantage in the market.

The figure below aim to highlight the benefits of the supply chain management stated by several researchers.

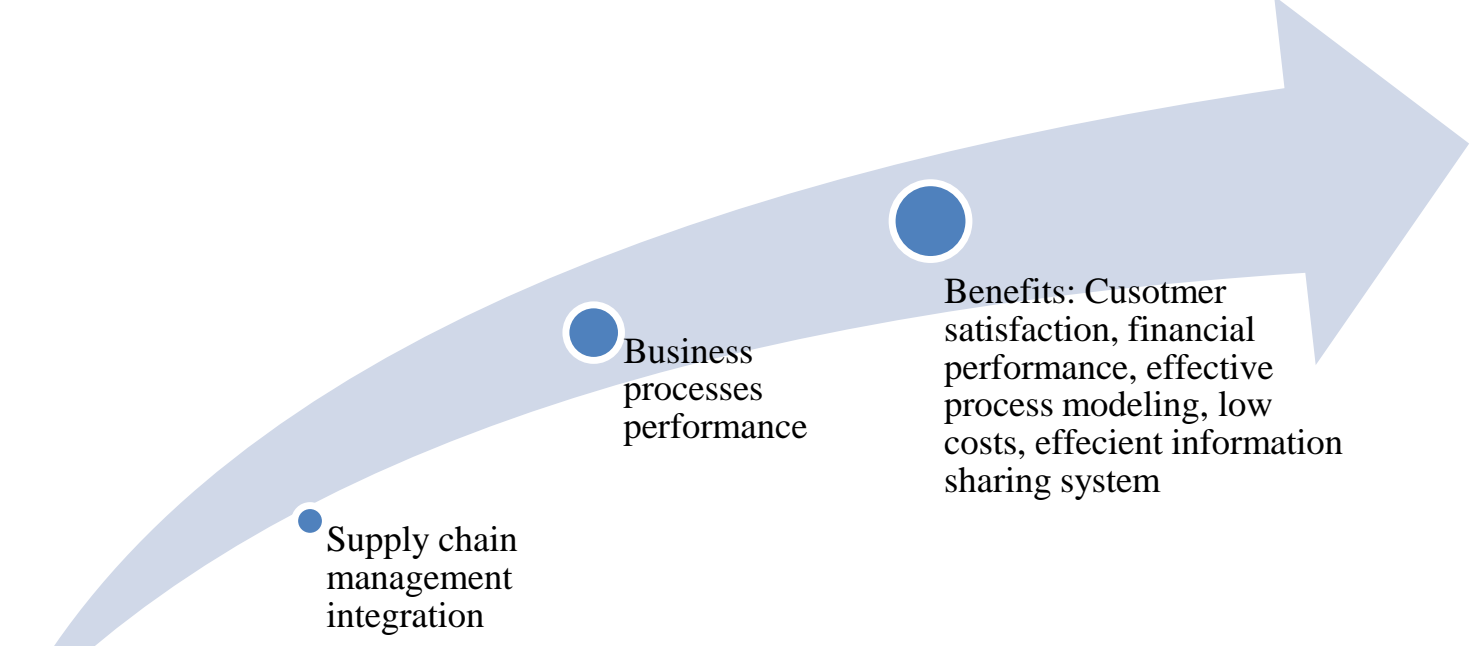

Source: Alsagheer et al. (2011).

Figure 1. Agreed benefits of an integrated supply chain management.

There are still many unstated facts about the supply chain management impact on the processes but we will have to skip them due to the paper limitation.

\section{Research Methodology}

This research has been carried out within a company called El Auras located in the east of the country with its headquarters in Algiers. The company has provided us with the financial situation for the years 2018 and 2019 and a briefing of their current processes.

The main objective of the research is show the benefit of supply chain management and its impact on improving efficiency and results.

As a first step we followed a quantitative research model, we used the known accounting and financial formulas to calculate the rates and the turnover of the few indicators listed in the table below. We couldn't calculate all relevant indicators due to the paper limitation "Number of pages".

For the purpose of this paper, we focused the investigation on a few processes such as production, inventory, financial turnover (ROI) and worker productivity.

As a second step we followed a qualitative research model, labelling the accounting and financial results into a non-structured questionaires, used for our interview with the different managers in the company. 
Thoth Publishing House

The indicators and the interview results will help us to debate our hypothesis:

- Existence of a co-relation between the supply chain management and the processes performances.

- Supply chain management positive impact on the process performances.

- Supply chain management usage to encourage automation which results into boosting employee satisfaction.

A very important note is that El Auras was following the classical way of management all the way until Feb 2019, when a group of experts from France visited the company and brought to the attention of the CEO the need to start implementing modern supply chain management transformation processes as their investigation uncovered excessive waste in resources.

As a first step of the research, the company has provided us with the financial situation for 2018 and 2019 and we used the financials calculus to measure the indicators performance. The table below shows the calculation of the indicators subjected to our study.

Table 1. Financial situation and the calculation of the indicators

\begin{tabular}{|c|c|c|c|}
\hline Indicator & Rule & 2018 & 2019 \\
\hline \multicolumn{4}{|l|}{ Financial perspectives } \\
\hline $\begin{array}{l}\text { ROI (rate of financial } \\
\text { turnover) }(\%)\end{array}$ & $\begin{array}{l}\text { (Yearly net results / } \\
\text { private funds) } * 100\end{array}$ & $\begin{array}{l}(30.979 .285,84 / \\
600.000 .000,10) * 100 \\
=5,16 \%\end{array}$ & $\begin{array}{l}(39.979 .285,84 / \\
490.000 .000,10) * 100 \\
=8,15 \%\end{array}$ \\
\hline Rate of net benefit (\%) & $\begin{array}{l}\text { (year net } \\
\text { result/capital fund) * } \\
100\end{array}$ & $\begin{array}{l}(30.979 .285,84 / \\
390.000 .000) * 100= \\
7,94 \%\end{array}$ & $\begin{array}{l}(39.979 .285,84 / \\
358.000 .152,92) * 100 \\
=11,16 \%\end{array}$ \\
\hline $\begin{array}{l}\text { Production cost per ton } \\
\text { (Dinar Algerian) }\end{array}$ & $\begin{array}{l}\text { total production cost } \\
\text { / Production volume } \\
\text { (ton) }\end{array}$ & $\begin{array}{l}292.369 .256,36 / 6356 \\
=45.998,93 \text { D.A }\end{array}$ & $\begin{array}{l}272.369 .256,36 / 6600 \\
=41.268,06 \text { D.A }\end{array}$ \\
\hline \multicolumn{4}{|l|}{ Customer perspectives } \\
\hline $\begin{array}{l}\text { Rate of defective units } \\
(\%)\end{array}$ & $\begin{array}{l}\text { (Number of defective } \\
\text { units / Number of } \\
\text { produced units) } * 100\end{array}$ & $\begin{array}{l}(21.062 / 60356) * 100 \\
=34,89 \%\end{array}$ & $\begin{array}{l}(15.630 / 66000) * 100 \\
=23,68 \%\end{array}$ \\
\hline \multicolumn{4}{|c|}{ Internal processes perspectives } \\
\hline $\begin{array}{l}\text { Rate of inventory } \\
\text { turnover (\%) }\end{array}$ & $\begin{array}{l}\text { Cost of sales / } \\
\text { Average inventory }\end{array}$ & $\begin{array}{l}28.429 \cdot 314,39 / \\
22.743 \cdot 562,50=1,24\end{array}$ & $\begin{array}{l}\text { 65.765.042,37 / } \\
62 \cdot 651 \cdot 944,25=1,04 \\
\end{array}$ \\
\hline $\begin{array}{l}\text { Rate of worker } \\
\text { productivity (Nr. } \\
\text { Produced units) }\end{array}$ & $\begin{array}{l}\text { Quantity of produced } \\
\text { units / total number } \\
\text { of workers }\end{array}$ & $\begin{array}{l}60356 / 275=219 \\
\text { Units }\end{array}$ & $\begin{array}{l}66000 / 250=264 \\
\text { Units }\end{array}$ \\
\hline
\end{tabular}

Source: Author contribution.

The table above reflects the calculation of the different indicators using the known accounting and financial formulas. We can clearly observe an improvement in the second year, most of the indicators have shown a better performance on the second year, whether in areas of reducing costs or reducing defective units to improve the assets turnover rate.

To not limit our study to numbers only, interviews were carried out with 22 managers from different departments. 
Table 2. Coding interview data

\begin{tabular}{|c|c|c|c|}
\hline Responses & Initial coding & $\begin{array}{l}\text { Concordant } \\
\text { respondent }>9\end{array}$ & Focused coding \\
\hline \multirow[t]{3}{*}{ Interviews data } & Reduce production costs & $18 / 22$ & \multirow{3}{*}{$\begin{array}{l}\text { The main focus of SCM is to } \\
\text { improve efficiency, how } \\
\text { products gets into the company } \\
\text { and arrive to the customer, an } \\
\text { efficient SCM boost the ROA, } \\
\text { impacting both ROI and assets }\end{array}$} \\
\hline & $\begin{array}{l}\text { Maximize the assets and } \\
\text { profit turnover }\end{array}$ & $19 / 22$ & \\
\hline & \multicolumn{2}{|l|}{ Average: 18,5} & \\
\hline \multirow[t]{3}{*}{ Interviews data } & $\begin{array}{l}\text { Reduce defective units } \\
\text { rate and eliminate non- } \\
\text { conforming products }\end{array}$ & $12 / 22$ & \multirow{3}{*}{$\begin{array}{l}\text { The SCM has a big impact on } \\
\text { the production process and } \\
\text { information sharing process, } \\
\text { since the SCM objective is to } \\
\text { link all the different processes } \\
\text { to obtain the best process } \\
\text { outcome, it encourage } \\
\text { automatic production, which } \\
\text { has a better impact and offer a } \\
\text { better control of the process } \\
\text { and eliminate unnecessary } \\
\text { waste and avoid the usage of } \\
\text { the unnecessary resources. } \\
\text { Proved efficiency in the } \\
\text { information sharing area. }\end{array}$} \\
\hline & $\begin{array}{l}\text { Increase the employee } \\
\text { satisfaction and boost } \\
\text { their loyalty and willing } \\
\text { to comply by the } \\
\text { company policies }\end{array}$ & $15 / 22$ & \\
\hline & \multicolumn{2}{|l|}{ Average: 13,5} & \\
\hline
\end{tabular}

Source: Author contribution.

\section{Results and Discussion}

Quantitative discussion:

As per the calculation in the table 1 , we can clearly notice that the $2^{\text {nd }}$ year rates are better than the $1^{\text {st }}$ year rates, which confirms the hypotheses of "Existence of a co-relation between the supply chain management and the processes performances" and "Supply chain management positive impact on the processes performances".

For instance the rate of financial turnover has noticeably increased by $2,99 \%$, jumping for $5,16 \%$ in 2018 before the adaptation of the supply chain management strategy to 8,15\% in 2019 after adapting the supply chain management strategy.

A similar increase has been noticed in the rate of net benefit, the rate has increased with $3,22 \%$, jumping from 7,94\% in 2018 to $11,16 \%$ in 2019. Another positive indicator has been noticed is the control of the production cost per ton, it dramatically decreased from 45 998,93 Dinar Algerian in 2018 to just 41 268,06 Dinar Algerian in 2019, a considerable decrease and a noticeable achievement in such a short term "One year".

The last indicator of Worker productivity support the hypothesis of "Supply chain management to encourage automation which results into boosting employee satisfaction". This can be noticed in term of values and numbers by seeing the increased rate of worker productivity and decreased rate of the defect units. As per the calculation in the table 1, we notice that the worker productivity rate has increased with 45 units. Jumping from 219 units in 2018 to 264 units in 2019, while decreasing the number of the defect units from 21062 units in 2018 to just 15630 units in 2019. 


\section{Qualitative discussion:}

According to the interviews with the 22 managers, supply chain management had a positive impact in different areas and processes, most respondents agree with the hypothesis that supply chain management encourages the automation of the production line to facilitate the control of the production line and limit the wasteful usage of the resources.

$82 \%$ and $86 \%$ of respondents, respectively, believe that supply chain management has a positive impact on reducing costs and maximizes the assets turnover rate.

$54 \%$ of respondents agree with the idea that supply chain management helps decrease the defect unit's rate due to the automatic production line, but they are still subject to external factors such as employee negligence.

$68 \%$ of respondents agree with the fact that supply chain management boosts the employee satisfaction through increasing their loyalty rate. Supply chain management has a big impact on the employee as it maximizes the usage of the assets and resources in a positive return processes, it also obliges a clear communication inside the network which results into the employee being well informed about the company's situation and feeling part of the greater aspect of things, which boosts their loyalty and integration.

\section{Conclusion}

Supply chain management is a requirement that companies can no longer ignore. The rapid rate of change within the markets and the globalization of competition are strong driving factors that can very easily break a company and push it out of the scene.

Supply chain management is needed to ensure that a company can respond to the shifts in the market and the requirements of customers in a timely and efficient manner.

As we have indicated in this paper, supply chain management is an efficient way of improving the overall performance of the company and ensuring that the way forward is secured.

This research started by a brief analyzis of the existence literature review, followed by a brief case study of the company named El Auras.

Few financial indicators were selected due to the paper limit, however, the research aimed to remain clear for the reader without getting into accounting and financial details.

According to the results, we can clearly observe that the company has made an improvement in term of rates on the second year and after following of the supply chain management practices and the acquisition of automatic production line. Not only was the improvement clear but also quite rapid as the results were clearly visible from one year to another.

Extrapolating from the results obtained in this case study, it can be advised for any company still running its operation through traditional means and relying mostly on manual processed to invest in the development of their supply chain as supply chain management and automation are the way of the future and are becoming a necessity for companies across the world in order to be able to survive.

If companies in developing countries want to keep pace with the global markets and have a fighting chance in maintaining a healthy and positive financial standing, they need to ensure that they are operating at optimal levels and reducing their costs and waste while ensuring the best utilization of their assets.

At last the paper has shed the light to additional research; supply chain management impact on processes researchers shall separate each process and study it apart, in order to have a full manipulation of data and a full control of the key variables and to be able to easily remain within the study target.

\section{References}

[1]. A .A. Thatte (2007), "Competitive advantage of a Firm Through Supply Chain Responsiveness and Supply Chain Management Practices", Published PhD Dissertation. University of Toledo. 
[2]. Alsagheer et al. (2011), Impact Of Supply Chain Integration On Business Performance And Its Challenges, International Journal of Economics and Business Research 10(12):79-92.

[3]. Trkman, P., \& Groznik, A. (2006). Measurement of Supply chain integration benefits. Interdisciplinary Journal of Information, Knowledge, and Management, 1, 37-45.

[4]. Najmi A., Gholamian M. R., Makui A. (2013), Supply chain performance models: A literature review on approaches, techniques, and criteria. Journal of Operations and Supply Chain Management, Volume 6, Nr 2, pp. 94 - 113.

[5]. Felea M, Albastroiu I. (2013), Defining the Concept of Supply Chain Management and its Relevance to Romanian Academics and Practitioners, Amfiteatru Economic, Volume no. 15, issue no.33, pp. $74-88$.

[6]. Wong W.P. and Wong K.Y. (2007) 'Supply chain performance measurement system using DEA modeling', Industrial Management \& Data Systems, Volume 107, No 3, pp. $361-381$. 